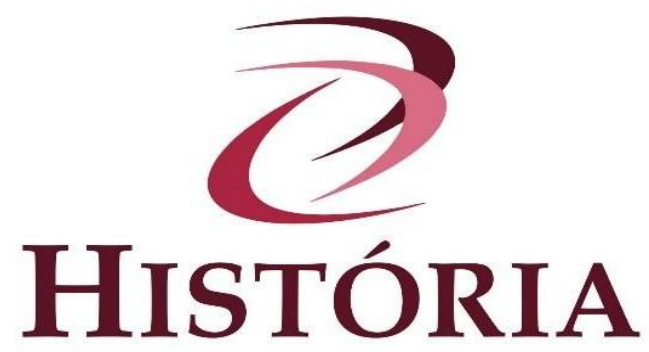

\title{
A Construção Histórica do Gênero Feminino na Narrativa Fílmica de "Desmundo"
}

\author{
The Historical Construction of the Female Gender in the Film "Desmundo"
}

\section{La Construcción Histórica del Género Femenino en la Narrativa de la Película "Desmundo"}

\author{
Gustavo Batista Gregio* \\ Sandra de Cássia Araújo Pelegrini**
}

\begin{abstract}
Resumo: O objetivo do artigo é refletir como é construída a imagem feminina na narrativa audiovisual do filme histórico "Desmundo", lançado em 2002, sob a direção do cineasta francês Alain Fresnot. O longa-metragem é uma livre adaptação do romance literário da escritora Ana Miranda, publicado em 1996. Assim, debatemos como os relatos históricos influenciaram na construção do gênero feminino, e como a narrativa fílmica representa esses aspectos historicamente arquitetados pelo poder masculino, por meio da protagonista Oribela. A personagem foi enviada forçosamente de Portugal para o Brasil, pela Coroa portuguesa, com o auxílio da Igreja Católica, em meados do século XVI, para casar-se com um colono português. Desta forma, a personagem dialoga com a história das mulheres, representando a trajetória de submissão e dominação do gênero feminino da História do Brasil.
\end{abstract}

Palavras-chave: Brasil. Cinema. Mulheres.

\begin{abstract}
The purpose of the article is to reflect on how the female image is constructed in the audiovisual narrative of the historical film "Desmundo", launched in 2002, under the direction of the French filmmaker Alain Fresnot. The feature film is a free adaptation of the literary novel by writer Ana Miranda, published in 1996. Thus, we debate how historical reports influenced the construction of the female gender, and how the film narrative represents these aspects historically architected by male power, through the protagonist Oribela. The character was forcibly sent from Portugal to Brazil, by the Portuguese Crown, with the help of the Catholic Church, in the middle of the 16th century, to marry a Portuguese settler. In this way, the character dialogues with the history of women, representing the trajectory of submission and domination of the female gender in the History of Brazil.
\end{abstract}

Keywords: Brazil. Cinema. Women.

Resumen: El propósito del artículo es reflexionar sobre cómo se construye la imagen femenina en la narrativa audiovisual de la película histórica "Desmundo", estrenada en 2002, bajo la dirección del cineasta francés Alain Fresnot. El largometraje es una adaptación libre de 
la novela literaria de la escritora Ana Miranda, publicada en 1996. Así, debatimos cómo los reportajes históricos influyeron en la construcción del género feminino, y cómo la narrativa fílmica representa estos aspectos históricamente construidos por el poder masculino, a través de el protagonista Oribela. El personaje fue enviado a la fuerza desde Portugal a Brasil, por la Corona portuguesa, con la ayuda de la Iglesia Católica, a mediados del siglo XVI, para casarse con un colono portugués. De esta manera, el personaje dialoga con la historia de la mujer, representando la trayectoria de sumisión y dominación del género femenino en la Historia de Brasil.

Palabras clave: Brasil. Cine. Mujer.

\section{O feminino nas narrativas audiovisuais do cinema: algumas reflexões}

As mídias visuais têm a capacidade de reproduzirem as mais variadas formas de estereótipos masculinos e femininos em suas linguagens. Esses arquétipos, muitas vezes são pautados em características historicamente construídas a partir do patriarcado. Sistema estrutural, que durante séculos outorgou ao homem branco heterossexual, poder, autonomia e dominação sobre os demais indivíduos, seja na esfera pública, como na privada, controlando também as expressões e manifestações humanas.

Nesse sentido, os gêneros femininos e masculinos foram historicamente arquitetados a partir da determinação biológica e sexual, ou seja, dos homens como superiores e dominantes, constituídos como detentores da razão e do conhecimento. E as mulheres, como indivíduos inferiores, submetidas a exclusão da vida pública e dos espaços de poder, condicionadas diretamente a situações íntimas da vida doméstica. Ainda hoje, o ethos masculino é tomado como modelo regulador dos comportamentos e hierarquias dos indivíduos, conferindo poder e legitimidade aos homens.

Desta forma, as narrativas visuais e audiovisuais, como é o caso das narrativas cinematográficas, ainda vêm produzindo e reproduzindo discursos subjetivos da mulher a partir da heteronomia, fundamentados através dos paradigmas da ordem patriarcal de outrora. De acordo com César (2011), essas subjetividades contidas na cultura visual, muitas vezes colocam as mulheres em papéis, normalmente estereotipados, que perpassam modelos historicamente construídos, “desde a 'rainha do lar' e 'mãe devota', uma imagem muito utilizada no campo da publicidade doméstica, como as de margarina, do sabão em pó e dos eletrodomésticos, à mulher liberada dos comerciais de cigarro e carros, chegando até à 'piranha' dos anúncios de cerveja” (CESAR, 2011, p. 188).

Assim, as representações da mulher ou do feminino no cinema, de modo geral, não escapam desse padrão de representação e comportamento androcêntrico. Uma vez que como personagens, as mulheres, com frequência, precisam ultrapassar barreiras socioculturais 
preestabelecidas, moldadas por visões sexistas e misóginas, adquiridas mediante interpretações ligadas a natureza humana e aos padrões biológicos modeladores dos aspectos físicos e psicológicos dos gêneros.

A narrativa cinematográfica ao estigmatizar as personagens femininas contribuí para sua marginalização e estereotipização. Visto que as mulheres serão representadas, de um lado, a partir do modelo de "boa mulher", relacionado ao recato, virtude e dedicação. Do outro, por meio do paradigma de "mulher mundana", que conecta a figura feminina a arquétipos levianos, impuros e luxuriosos. Onde o primeiro é valorizado e o segundo é combatido.

Kaplan (1995), ao analisar a representação cinematográfica, sobretudo, a hollywoodiana, afirma que essas narrativas são carregadas de valores e signos patriarcais, "que sustenta nossas estruturas sociais e que constrói a mulher de maneira específica maneira tal que reflete as necessidades patriarcais e o inconsciente patriarcal" (KAPLAN, 1995, p. 45). Estes aspectos atuam na construção estereotipada dos gêneros, principalmente do feminino, reafirmando costumes e valores relacionados ao modelo de "boa mulher" e/ou "sexo frágil". A autora entende que essas narrativas "trazem uma ordem social a ser purgada, um conjunto de imperativos éticos que é preciso elucidar" (KAPLAN, 1995, p. 46).

Na perspectiva de Viana (2009), a cultura visual também representa a mulher por meio da sensualidade e beleza, isto é, "de acordo com o padrão dominante de beleza ou com uma cena marcada por sensualidade" (VIANA, 2009, p. 36). Nessas imagens, o corpo feminino aufere destaque, colocado como objeto de atração e desejo do gênero masculino e feminino. Segundo Silva (2016), a naturalização desses padrões estéticos resulta na "[...] exclusão de profissionais que não se enquadram nesse ideal de beleza [...]" (SILVA, 2016, p. $38)$.

Para Del Priore (2000), nas mulheres públicas, como as atrizes de cinema, a beleza e elegância são atributos vistos como um dever cultural, onde a chamada "boa aparência", é associada ao sucesso e credibilidade. Logo, as mídias visuais, como "a fotografia, o cinema e a imprensa divulgam padrões que devem ser seguidos, excluindo aquelas que deles não se aproximam" (DEL PRIORE, 2000, p. 72).

Deste modo, de acordo com os critérios estabelecidos na estética cinematográfica, as mulheres que não representam esse "ideal de beleza" ou de "boa aparência", são subjugadas a outros estereótipos alegóricos e caricatos, carregados de valores depreciativos como magreza extrema, feiura e velhice. Por exemplo, “a obesidade [...] tornar-se um critério determinante 
de feiura, representando o universo vulgar, em oposição ao elegante, fino e raro" (DEL PRIORE, 2000, p. 75).

Não raro, segundo Kaplan (1995), o gênero feminino na narrativa fílmica é moldado, especialmente através do voyeurismo masculino, característica que "está ligada ao instinto escopofílico (o prazer masculino de transferir o prazer de seu próprio órgão sexual para o prazer de ver outras pessoas fazendo sexo) (KAPLAN, 1995, p. 53). A autora assegura que a linguagem cinematográfica se baseia neste instinto, alegando que "o espectador, obviamente, está na posição de voyeur quando há cenas de sexo na tela, mas as imagens das mulheres na tela são sexualizadas, não importa o que estas mulheres estejam literalmente fazendo ou em que espécie de enredo estão envolvidas" (KAPLAN, 1995, p. 53).

A autora complementa sua análise postulando que os espectadores estão "na posição de voyeur quando há cenas de sexo na tela, mas as imagens das mulheres na tela são sexualizadas, não importa o que estas mulheres estejam literalmente fazendo ou em que espécie de enredo estão envolvidas" (KAPLAN, 1995, p. 53). Por esse ângulo, os códigos e signos codificados na linguagem cinematográfica, expõem a ideia de que o corpo feminino "é um espetáculo a ser olhado, e que essa deve conhecer o seu lugar (provavelmente à beira de um tanque ou fogão)" (GUBERNIKOFF, 2009, p. 72). Portanto, as subjetividades presentes nessas visualidades do cinema exaltam os signos socioculturais de dominação, onde a força masculina do homem branco é figura ativa e heroica, e a mulher como simulacro inferior, “[...] depositária do desejo masculino, aparecendo de modo passivo e não ativo" (KAPLAN, 1995, p. 47).

Nesta ótica, o gênero feminino é quase sempre associado a ação simbólica masculina, delimitando a atuação da mulher, como considera Lauretis (1993), “a uma ordem social e natural específica, define-lhe certas proposições de significado, fixa-a numa determinada identificação" (LAURETIS, 1993, p. 99). Por conseguinte, embora ocorra alguma alteração na construção do feminino durante o desenvolvimento da narrativa fílmica, a mulher, ao final da história, "voltará sempre para seu devido lugar social e familiar. Caso isso não aconteça, no transcorrer do enredo, será castigada por sua transgressão" (GUBERNIKOFF, 2009, p. 73). A maioria das narrativas cinematográficas, especialmente do cinema comercial, "são construídas com base nesses estereótipos, escondendo-se atrás de um romantismo exagerado e sem nenhuma indicação sobre o modo real de sua vida" (GUBERNIKOFF, 2009. p. 73).

Desta forma, as narrativas audiovisuais do cinema, ainda hoje, representam o gênero feminino por meio de estereótipos que envolvem aspectos históricos e socioculturais de 
comportamento normativo, reproduzindo ideologias dominantes e discursos oficiais do gênero masculino. Nessa dialética, quando a representação feminina "está de acordo com o discurso oficial de dado momento histórico é amplamente divulgada, já a representação que não se insere nos moldes tradicionais ou na ótica de uma cineasta com posicionamento crítico não terá a mesma visibilidade" (KAMITA, 2017, p. 1394). Sendo assim, o gênero feminino é constituído com base no patriarcado, criando uma objetificação da mulher e reforçando a hierarquia sexual entre os gêneros.

\section{A representação da mulher na história do filme "Desmundo"}

"Desmundo" foi lançado em 2002, coproduzido pelo Brasil e Portugal, sob a direção do cineasta francês Alain Fresnot e roteiro da brasileira Sabina Anzuategui, com duração de 100min. O longa-metragem é uma livre adaptação do romance literário escrito por Ana Miranda de 1996. Trata-se de um filme histórico, falado em português quinhentista, exibido com legendas em português contemporâneo e que tem como tema o início da "colonização" portuguesa no Brasil. O título faz alusão a um "não mundo" ou, fim de mundo, um lugar de barbárie, sem leis, onde todos os indivíduos, sobretudo, as mulheres são exploradas, subjugadas e marginalizadas. $\mathrm{O}$ roteiro dialoga intimamente com a História brasileira e o cotidiano colonial do século XVI.

A roteirista Anzuategui (2006) destaca que além do texto original de Ana Miranda, outros escritos históricos embasaram a construção da narrativa fílmica, especialmente registros e relatos de viajantes, cartas entre jesuítas e com a Coroa portuguesa e descrições antropológicas da vida cotidiana e dos costumes coloniais. Essas fontes delegavam características para o gênero feminino no período, especialmente para as mulheres brancas lusitanas, como é o caso da protagonista do filme, Oribela, interpretada pela atriz Simone Spoladore. A personagem é uma jovem órfã, de aproximadamente 15 anos de idade, que vivia em um convento em Portugal e que foi enviada, junto de mais cinco moças, para a colônia na América pela Coroa portuguesa com o auxílio da Igreja Católica, para estabelecerem matrimônios com colonos portugueses.

De acordo com os relatos históricos, a política de povoamento da colônia também incluía o envio forçado de indivíduos que não eram bem-vindos na Metrópole para o cumprimento de castigos ou punições temporárias ou permanentes, sejam por terem cometidos crimes contra as leis da Coroa ou transgressões morais. O envio incluía, segundo o historiador Vainfas (1989, p 31), desde: 
[...] os freiráticos que invadiam mosteiros para arrebatar as esposas de Cristo; os que desonestassem virgens ou viúvas honestas; os que fornicassem com tias, primas e outras parentas; os que violentassem órfãs menores sob tutela; os que, vivendo da hospedagem alheia, dormissem com parentas, criadas ou escravas brancas do anfitrião; os que dormissem com mulheres casadas, e as próprias adúlteras, em certas circunstâncias; as amantes de clérigos; os alcoviteiros de freiras, virgens, viúvas e parentas dentro do quarto grau; as maridos que matassem esposas adúlteras, caso não provassem o casamento com as mulheres assassinadas.

Assim, o "povoamento" portugueses, contou com todos os tipos de indivíduos, como homicidas, estupradores, adúlteros, "feiticeiras", bígamos, hereges, entre tantos outros. Esses indivíduos, sobretudo, as mulheres, muitas delas trazidas forçosamente, eram submetidas ao sistema de dominação patriarcal, no qual eram obrigadas a se casarem muito jovens, como é o caso das personagens retratadas no filme. Esses matrimônios objetivavam especialmente a procriação, que visava resguardar a linhagem lusitana e o poder da Corte portuguesa nas novas terras, pois na colônia existiam apenas mulheres indígenas, as quais eram vistas como figuras impuras e demonizadas pela Coroa e a Igreja Católica.

Segundo a percepção dos colonos cristão, especialmente dos jesuítas, os pecados dos gentios não tinham limites e a colônia era povoada por degenerados, tendo em vista que pairava no ar um delírio sexual, impulsionado pelos indígenas que permaneciam constantemente desnudos. Logo, as novas terras eram perigosas para os cristãos, visto que "existia um contágio doentio com o pecado" (BAUER, 2001, p. 118). Os jesuítas demonizaram as populações indígenas e seus costumes, assegurando que as uniões ou casamentos existentes entre colonos portugueses e índias não eram considerados matrimônios cristãos. Assim, o discurso político e religioso era orientando, de acordo com Figueiredo (2017, p. 170):

[...] por um caráter nitidamente racial: tratava-se da preservação da pureza de classe dos "homens bons", o que, em última instância, reforçava a elite em âmbito local. Decorreram daí todos os esforços para que, através de certos casamentos, a ordem colonial pudesse ter sua continuidade garantida.

Nesse sentido, a imagem feminina no Brasil surgiu sob a luz de estereótipos, que delegavam sentidos aos gêneros masculino e feminino naquela sociedade, outorgando paradigmas socioculturais que eram naturalmente incorporados, ou seja, do homem como provedor e líder da família, vinculado aos espaços públicos de poder e da mulher, como donade-casa, submetida a vida doméstica e ao contínuo cuidado dos filhos.

Desta forma, o imaginário colonial construiu dois importantes aspectos relacionados à imagem da mulher. $\mathrm{O}$ primeiro, correspondente as indígenas e as escravas negras, que eram concebidas como simples mão-de-obra para o trabalho e como objetos sexuais em constante intercurso sexual com os "colonizadores". O segundo, acerca das mulheres brancas europeias, como é o caso de Oribela, que precisavam ser o oposto das duas primeiras, especialmente no 
que diz respeito ao corpo e a sexualidade. Sendo assim, o sacramento do matrimônio e a maternidade tornaram-se uma das bases do discurso simbólico de dominação e opressão sexual do Estado português e do cristianismo proferido as mulheres. Onde era preciso manter a manutenção dos dogmas cristão no interior das famílias, como para justificar, segundo a historiadora Del Priore (1990), “[...] a instalação de um aparelho burocrático e afirmar o poder da Igreja no Novo Mundo" (DEL PRIORE, 1990, p. 174).

Os teóricos cristãos encontraram nas palavras bíblicas, justificativas para a Igreja exercer amplo controle sobre a vida e a sexualidade feminina. Ou seja, sustentavam os princípios que “[...] desde Eva, as tentações da carne e as perversões sexuais surgem do sexo feminino" (RAMINELLI, 2017, p. 42). Portanto, as mulheres precisavam ser controladas dentro da estrutura familiar cristã. Nesse âmbito, o arcabouço matrimonial e familiar constituído por pai, mãe e filhos, e endossado pelos preceitos da tradição cristã europeia, embora, segundo Carmo (2019), tenha se constituído um privilégio da elite branca local, também se tornou uma das garantias de status e de segurança a todos os colonos, porque estava na contramão das práticas existentes.

Nesse contexto, Igreja e Estado perceberam a necessidade de enviar mulheres de Portugal, as quais eram advindas dos mais variados segmentos, desde as classes mais altas, bem como órfãs pobres e prostitutas. Registros da época, como os escritos históricos do padre Manuel da Nóbrega para o Rei João III, de janeiro de 1550, utilizados na narrativa fílmica de "Desmundo", evidenciam esse cenário. Na carta, o cardeal descreve as reais condições da "colonização" e afirma ser extremamente necessário o envio de órfãs e mulheres lusitanas para ajudar no povoamento das terras, para que elas se desposem com os colonos, evitando os mancebos e concubinatos com as nativas.

Muitos cristãos, por serem pobres, se casaram com as mulheres negras da terra, mas bastantes outros voltarão para o nosso Reino por não os querermos absolver, ainda que tenham filhos, por serem casados em Portugal; e nas pregações muito os repreendemos. Se El-Rei determina povoar mais esta terra, é necessário que venham muitas mulheres órfãs e de toda a quantidade até meretrizes, porque há aqui várias qualidades de homens; e os bons e os ricos casarão com as órfãs; e deste modo se evitarão pecados e aumentará a população no serviço de Deus (LEITE, 1955, p. 79-80).

O diretor Alain Fresnot, ao utilizar esses fragmentos históricos da carta do Padre Manuel da Nóbrega para iniciar sua narrativa, busca situar historicamente sua obra a seu espectador, estabelecendo uma relação dialógica com a história que está narrando. Para Nunes (2017), essas mulheres enviadas de Portugal, vieram “cumprir aqui sua função de reprodutoras biológicas e sociais. Era necessário procriar para garantir a hegemonia branca da Metrópole também na Colônia; era preciso gerar filhas e filhos de sua própria raça e classe" 
(NUNES, 2017, p. 484). Pois, de acordo com Rezzutti (2018), também "fazia parte do processo de colonização o branqueamento da colônia" (REZZUTTI, 2018, p. 41).

Então, o envio dessas mulheres, como retratado na figura 1, é parte primordial do projeto colonizador do reino de Portugal e da Igreja Católica. Os arranjos matrimoniais que envolvem essas jovens foram elementos fundamentais no povoamento nas capitanias, como relevante instrumento de equilíbrio social, de segurança e de estabilidade econômica dos colonos portugueses. Os personagens masculinos almejam esses casamentos para ascenderem socialmente nas novas terras.

Figura 1. Desembarque das órfãs na colônia e a personagem Maria.
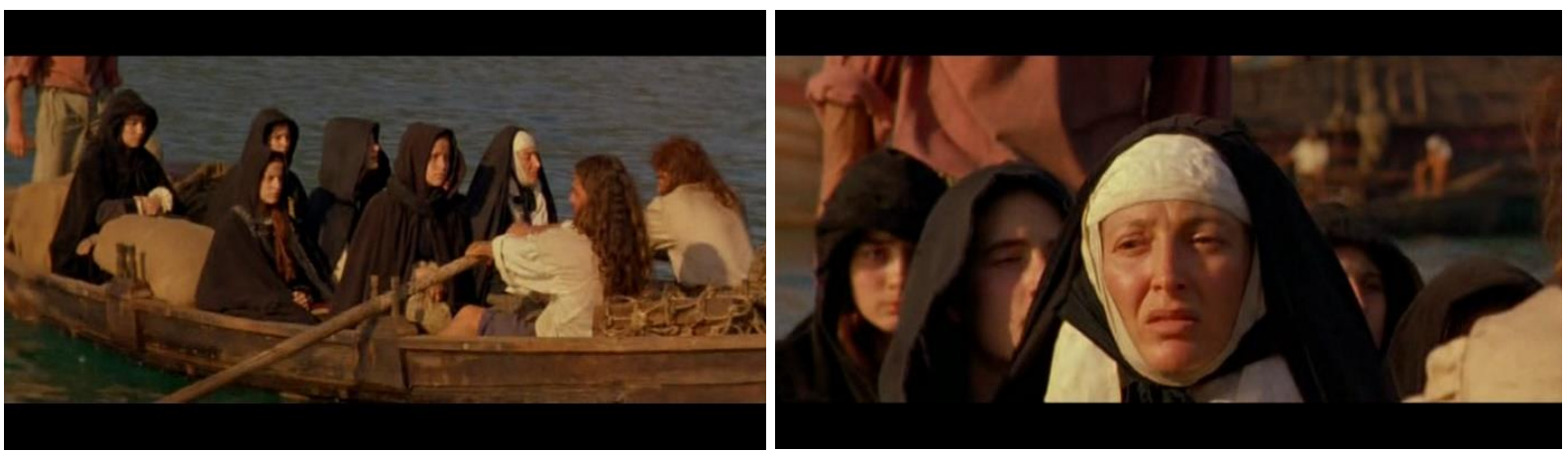

Fonte: frame extraído do filme "Desmundo", direção Alain Fresnot, 2002.

Na figura 1, destaca-se a presença de uma beata, a personagem Maria, interpretada pela atriz Debora Olivieri. A mulher é a responsável pelo cuidado no translado, como da educação e do preparo dessas jovens para o casamento. Historicamente, a presença dessas figuras religiosas durante as viagens também visava o cuidado e a vigilância dessas jovens mulheres, desde a saída do velho continente até o momento do matrimônio na colônia. Pois, de acordo com Ramos (2007), a presença dessas moças causava grande alvoroço na tripulação das embarcações, bem como, na colônia, e para que elas não fossem violadas sexualmente e permanecessem virgens até o matrimônio, essas autoridades religiosas as acompanhavam e as protegiam das agressões, relatando as possíveis ocorrências para a Coroa portuguesa, que punia rigorosamente os agressores, uma vez que essas mulheres eram objetos de investimento do Estado e da Igreja Católica.

A personagem Maria, além de acompanha-las, também está cumprindo uma condenação. A mulher era uma freira em Portugal, porém foi condenada por adultério, ao se envolver amorosamente e engravidar de um nobre portugueses, foi excomungada da Igreja e lhe tiraram o filho. E ainda, como castigo, foi enviada para a colônia. A personagem ao infringir os dogmas do cristianismo sucumbiu à força masculina, passando a viver sobre a 
tutela dos jesuítas, privada de cargo e de voz, reclusa em eternas penitências, jejuns e prostrações.

Essas religiosas ao desembarcaram no Brasil, especialmente durante o século XVI, vivenciaram variadas experiências de submissão, passividade e transgressão. Visto que até meados do século XVII, era proibida a criação de conventos na colônia. A Coroa e os colonos entendiam que essas instituições simbolizavam uma grande ameaça aos objetivos da "colonização", uma vez que retiravam da "sociedade parte de sua população potencialmente fértil" (NUNES, 2017, p. 484). Quando os conventos foram oficialmente autorizados, representavam um espaço de maior reclusão, porque as mulheres eram totalmente privadas de liberdade. Para elas, os conventos no Brasil constituíram-se em ambientes contraditórios. Nas palavras de Nunes (2017, p. 486):

Funcionavam como instrumentos eficazes de regulação de casamentos. Quando se tornava difícil casar "bem" todas as filhas, atraindo jovens ricos, a solução era casar apenas uma e encerrar as outras num convento. Segundo informações da época, era comum encontrar vários membros da mesma família em um único convento. Assim, a riqueza e o poder político de um pequeno grupo de famílias eram preservados. Histórias de mulheres enclausuradas contra a própria vontade, nesse período, não faltam. Todas elas com ingredientes trágicos e romanescos: loucura, noivados abandonados, fortunas perdidas.

No contexto histórico do filme, como não existiam conventos, o matrimônio ou a prostituição eram as únicas opções de sobrevivência de uma mulher lusitana recém chegada a colônia. Nesse sentido, Oribela e as demais jovens são preparadas pela personagem Dona Brites, interpretada pela atriz Beatriz Segal, para a cerimônia de apresentação aos noivos.

Durante a sequência, a velha senhora portuguesa reproduz o discurso patriarcal normatizador do corpo feminino perpetrado no período, ressaltando o modelo de "boa mulher". Para a personagem, a mulher precisa reconhecer o seu devido lugar nas relações sociais e familiares, ou seja, submissa às vontades e desejos dos maridos. Somente assim, elas não causariam problemas com os homens, não subvertendo o status quo, como observado no diálogo da figura 2.

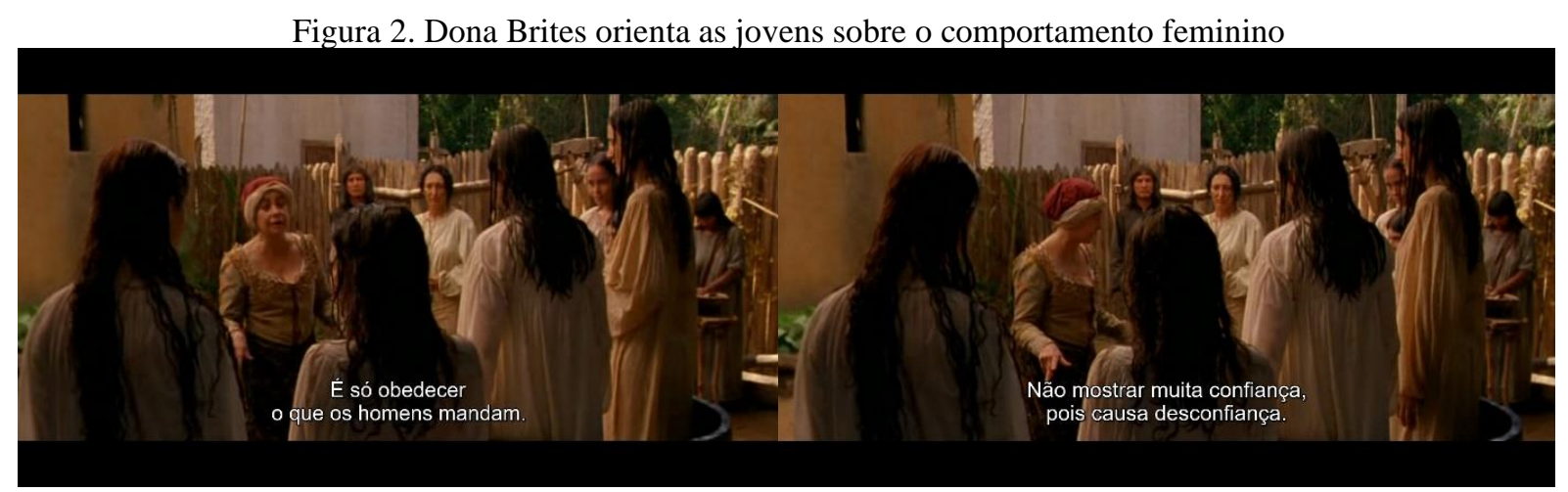

Fonte: frame extraído do filme "Desmundo", direção Alain Fresnot, 2002. 
Segundo Araújo (2017), a justificativa para essa subordinação era simples, os homens eram vistos como naturalmente e biologicamente superiores as mulheres, melhores condicionados fisicamente e mentalmente. Desse modo, caberia somente ao gênero masculino exercer autoridade e poder. Segundo a personagem Dona Brites, essas jovens precisavam ser modelos de boas mães e esposas, responsáveis pelo cuidado da casa, dos filhos e maridos. A alocução da personagem reforça a ideia da divisão sexual entre os gêneros por meio da natureza biológica e da estruturação corporal. Seu discurso é intimamente vinculado aos preceitos pregados pelas Igreja, ensinado pelos médicos e legitimado pelo Estado. Como representante do Estado português, é ela, juntamente do seu marido, o personagem governador, interpretado pelo ator José Eduardo, que são os responsáveis pela formação de cada casal.

Oribela é escolhida para ser esposa de Dom Alfonso Soares D’Aragão, interpretado pelo ator Cacá Rosset. Desesperada com a situação, acomete o homem com uma cusparada em seu rosto, figura 3. A atitude é considerada uma grave ofensa, o que revolta as autoridades e os colonos presentes na cerimônia, pois esse tipo de comportamento jamais caberia a uma mulher.

Figura 3. Oribela não aceita o pretendente como marido.
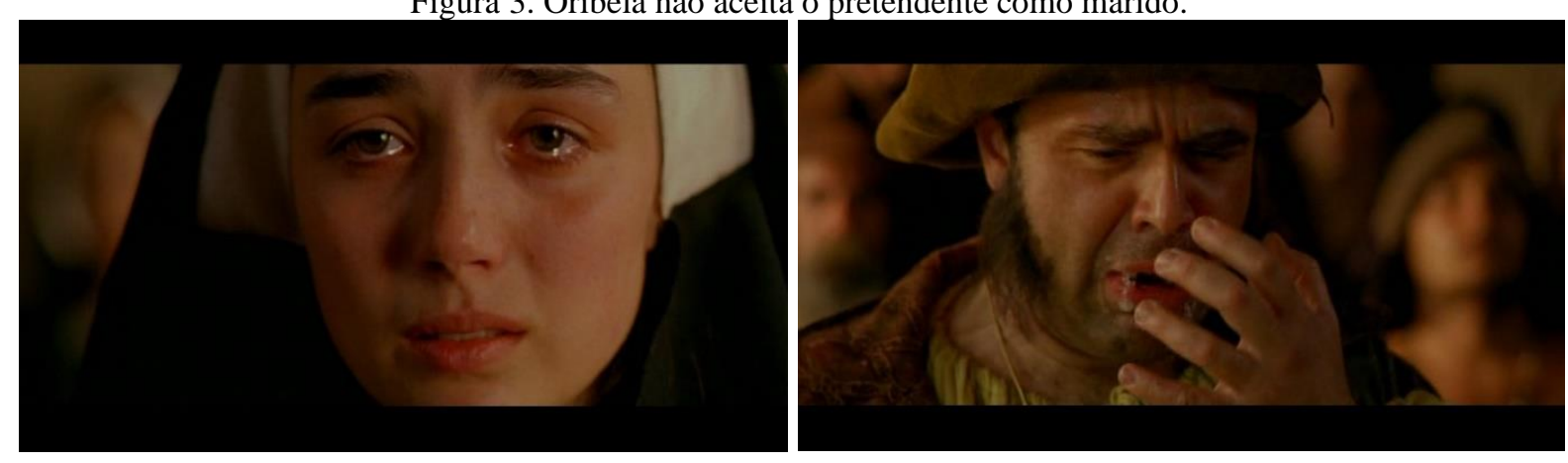

Fonte: frame extraído do filme "Desmundo", direção Alain Fresnot, 2002.

Ao quebrar o primeiro paradigma de "boa mulher", a personagem é punida com golpes de palmatoria, executados por Maria. Entretanto, apesar da agressão, ela acredita que seu ato de rebeldia fará com que nenhum homem tenha interesse em se casar com ela e poderá, assim, regressar para Portugal. Porém, ao contrário do imaginado, o personagem Francisco de Albuquerque, sobrinho do governador e rico proprietário de terras e de escravos, interpretado pelo ator Osmar Prado, a escolhe como esposa.

Francisco representa o legítimo homem colonial. Isto é, indivíduo extremamente machista e autoritário, detentor do poder e da razão. Embora também seja marginalizado e 
dominado pela estrutura colonial, ele é superior a muitas outras categorias dentro desse sistema. É autorizado a executar sua força, especialmente contra a esposa. Cabe postular que o gênero masculino é representando na narrativa fílmica a partir de estereótipos ligados à força, brutalidade e hostilidade. Os personagens são retratados por meio de modos rudes e grosseiros. Os homens estão sempre trajando roupas velhas e sujas, possuem a pele queimada do sol, aspecto utilizado para ressaltar o calor dos trópicos, e permanecem constantemente observando as mulheres com olhar de cobiça e desejo, como destacado na figura 4.
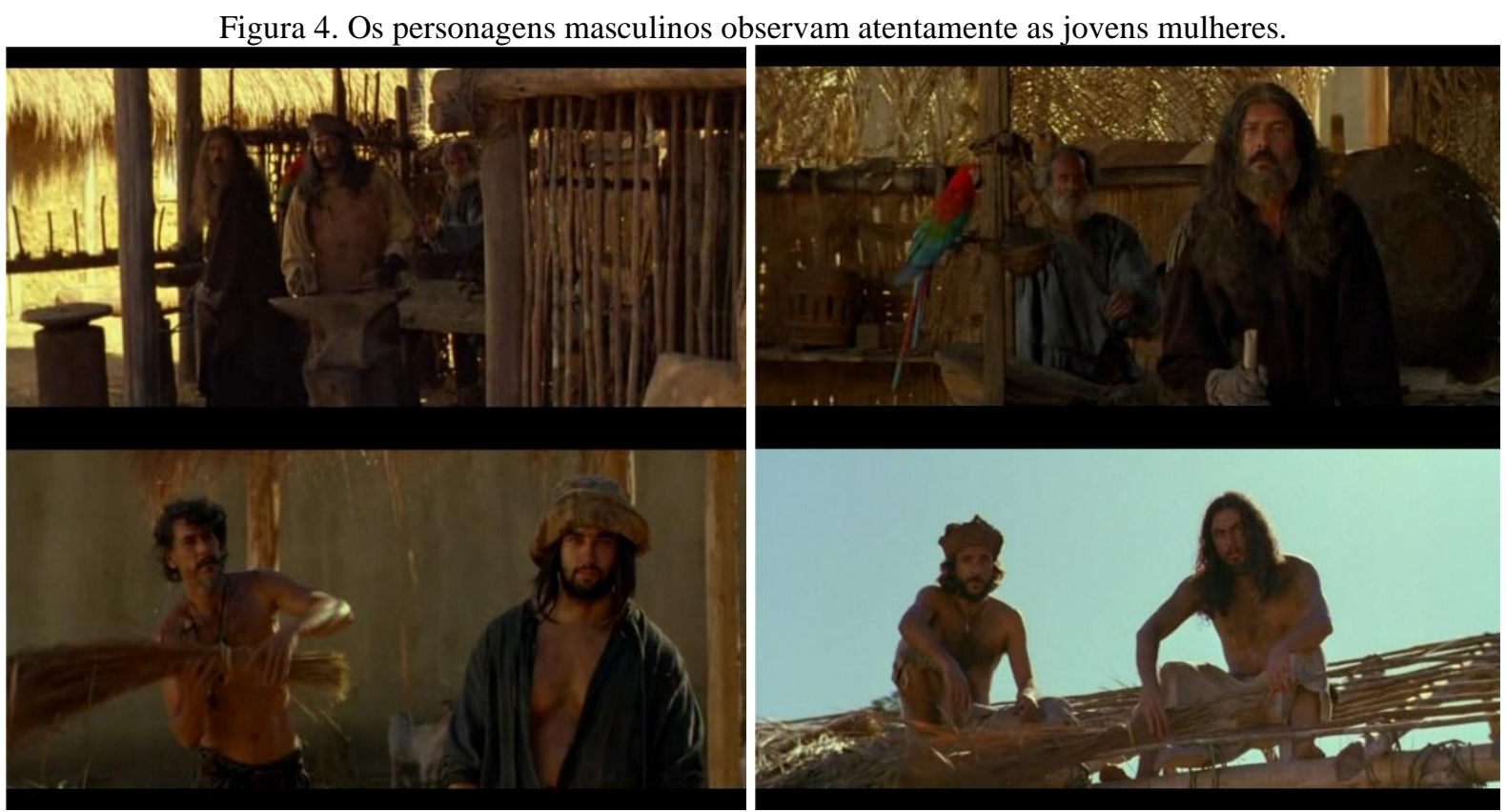

Fonte: frames extraídos do filme "Desmundo", direção Alain Fresnot, 2002.

No filme, o sacramento do matrimônio é realizado coletivamente. Um Padre jesuíta, interpretado pelo ator Olair Coan, é quem realiza a comunhão, figura 5. Em sua homilia, o religioso reafirma o discurso patriarcal de domínio dos homens sobre as mulheres, quando solicita que as jovens unam suas mãos a mãos dos homens, para que assim, diante de Deus, aceitem ser guiadas por eles. O sacerdote determina aos maridos total poder e controle sobre suas esposas e futuras filhas. Durante a pregação, o personagem também reforça a visão pejorativa que a Igreja tinha acerca dos indígenas, afirmando que os "negros da terra" ou "brasis", vivem como animais e que é preciso se afastar dessa realidade, aceitando o sagrado matrimônio. 
Figura 5. Cerimônia de casamento.

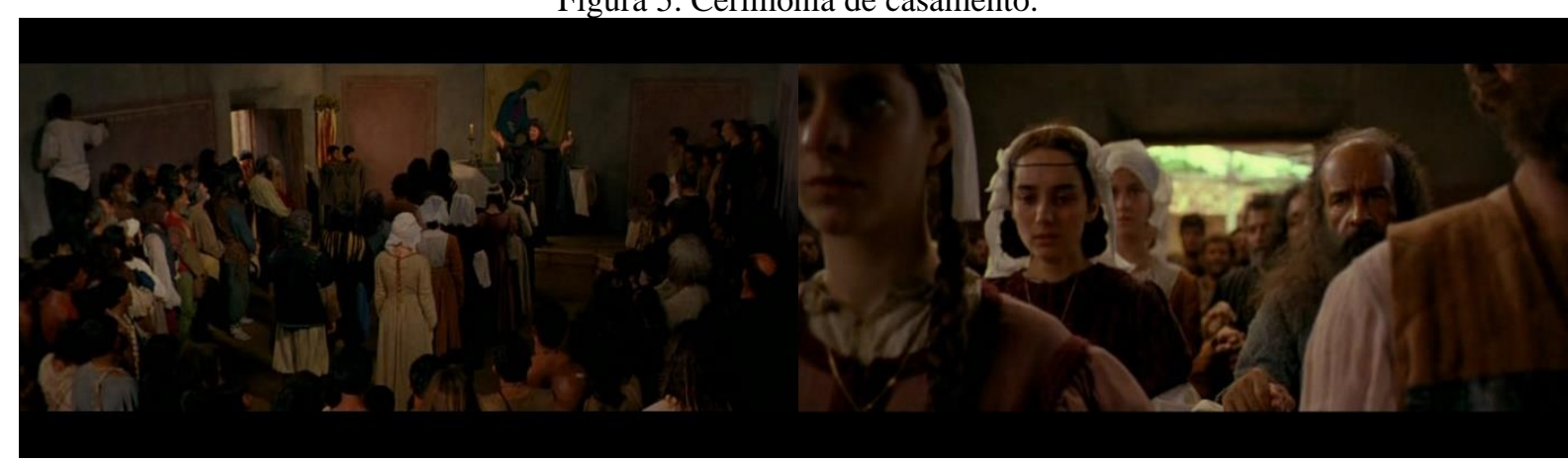

Fonte: frames extraídos do filme "Desmundo", direção Alain Fresnot, 2002.

O personagem, ao proferir essas afirmações, legitima o sistema e a força de dominação masculina, asseverando que nas mãos daqueles homens, fossem eles maridos, pais ou irmãos, encontra-se o poder sobre os demais indivíduos daquela sociedade, principalmente, das mulheres. Del Priore (1990) entende que a Igreja se utilizou desse discurso de opressão para validar o papel do gênero masculino no interior do matrimônio ampliando, portanto, seu controle sobre ambos, delegando que "deve o marido como cabeça que é da mulher, cuidar que esta cumpra os encargos da profissão cristã, que guarde promessa feita a Deus no batismo, de renunciar as pompas do mundo" (DEL PRIORE, 1990, p. 156).

Ainda, segundo Del Priore (2016), na percepção desses representantes da Igreja, a união matrimonial não deveria ser puramente por amor, mas por obrigação em garantir a procriação e missão divina na luta contra as tentações do adultério e dos desvios morais. Esse discurso, somado ao pensamento patriarcal, colocou o sacramento do matrimônio no centro dos interesses de poder.

Sob esse prisma, Freyre (2003) pondera que essas meninas e mulheres criadas nesses ambientes rigorosamente patriarcais "viveram sob a mais dura tirania dos pais - depois substituída pela tirania dos maridos" (FREYRE, 2003, p. 510). Como retratado no filme, o matrimônio era muitas vezes precoce e visava, além de conter a liberdade e os possíveis desejos sexuais das jovens, fortalecer a ideia de submissão sexual da mulher frente ao homem. $\mathrm{Na}$ ótica de Rezzutti (2018), “o exercício da sexualidade era um atributo puramente masculino; só o fato de a mulher pensar em ter prazer já a colocava junto às pecadoras e consumar o ato fora do casamento era a desgraça social" (REZZUTTI, 2018, p. 40).

Assim, sem possibilidade de fuga ou ascensão, a estrutura familiar torna-se o único e pequeno espaço de vivência da personagem Oribela, onde começa a sofrer todo tipo de violência física e simbólica, que visava “adestrar" suas ações e desejos. Desde a primeira noite de casada, ela é violentada, estuprada e agredida por Francisco. A despeito dessas 
práticas, Del Priore (1990) aponta que o pensamento patriarcal acreditava que as mulheres sofreriam um processo gradual de adestramento para se enquadrarem aos modelos de boas esposas e mães. Se opondo "à promiscuidade e à lascívia da mulher de classe subalterna, em geral negra, mulata ou índia, pivô da miscigenação e das relações interétnicas que justificaram por tanto tempo a falsa cordialidade entre colonizadores e colonizados" (DEL PRIORE, 1990, p. 48-49).

Além disso, de acordo com Pateman (1993), ao se casar, mulheres como Oribela, não careciam mais de ambições e deveriam viver onde e como seus maridos desejassem, porque "suas rendas e seus filhos eram propriedades de seu marido, exatamente como os filhos da escrava pertenciam a seu senhor (PATEMAN, 1993, p. 182). Na perspectiva da autora, isso era legitimo, em razão de que a "condição civil e legal de uma esposa se assemelhava à de um escravo. Pela doutrina legal comum do casamento, uma esposa, como um escravo, estava civilmente morta" (PATEMAN, 1993, p. 180). Portanto, para o pensamento patriarcal, Oribela tinha de ser uma esposa obediente e devota, serva fiel do esposo Francisco.

Após o casamento, é levada para a casa da sogra, a personagem Dona Branca, interpretada pela atriz Berta Zemel. A personagem é uma mulher viúva que veio para o Brasil com o filho. É retratada de maneira misteriosa, vive praticamente isolada no engenho da família no meio da floresta com escravos índios e sua outra filha, Viliganda, que tem uma “doença mental”. Sua relação com o filho Francisco é extremamente ambígua, ao mesmo tempo que demonstra autoridade sobre ele, também é profundamente submissa. A chegada de Oribela causa grande desconforto, pois ela percebe que corre o risco de perder a influência sobre o filho e o poder que exercia no engenho e na residência da família.

O fato, é que agora, Oribela não é apenas vigiada pelo marido, mas também pela sogra. Confinada a viver dentro do ambiente doméstico, ela dialoga com as demais mulheres lusitanas do período. De acordo com Carmo (2019), não era permitido que as mulheres casadas aparecerem sozinhas fora de casa. Em alguns casos, somente poderiam sair para frequentar missas, batizados e enterros, desde que tivessem autorização dos esposos.

A repressão familiar era extrema que quase não existiam espaços para a infidelidade feminina. E, se ocorresse qualquer tipo de dúvida sobre o caráter da mulher, eram intensamente punidas "mesmo que equivocada, de condutas reais ou supostas; a casada não pode sequer dar lugar a dúvidas infundadas, pois o peso da reputação era importantíssimo" (DEL PRIORE, 2016, p. 282).

Mesmo extremamente vigiada, Oribela acaba se interessando pelo personagem Ximeno Dias, um cristão novo, interpretado pelo ator Caco Ciocler. Ximeno é retratado como 
um homem simples e independente, que sobrevive capturando indígenas e vendendo-os como escravos para os colonos. O primeiro encontro entre os dois acontece na residência de Francisco, enquanto os homens fazem negócios. Na sequência da figura 06, Oribela e Ximeno trocam alguns olhares e um pequeno toque entre os dedos. Gesto que é percebido pelo marido e que causa grande adversidade a protagonista, que é agredida fisicamente e estuprada por Francisco.

Figura 6. A pequena aproximação de Oribela e Ximeno causa grande revolta em Francisco.
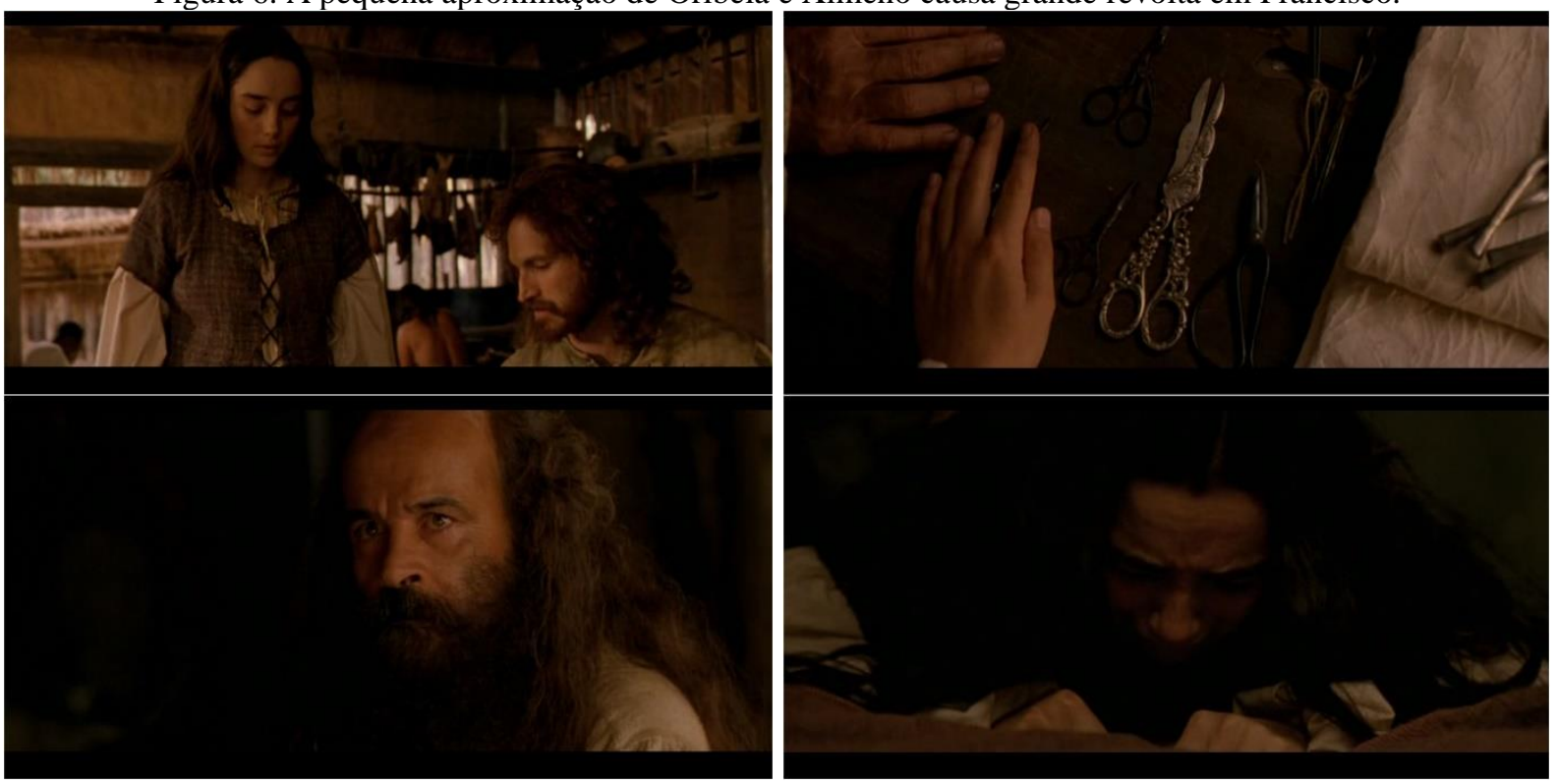

Fonte: frames extraídos do filme "Desmundo", direção Alain Fresnot, 2002.

Francisco justifica sua violência asseverando que a esposa agrediu sua honra enquanto homem. O personagem reproduz fisicamente na mulher o discurso de controle das vontades e desejos femininos, o qual deve controlar o corpo e a mente das mulheres. No filme, após o ocorrido, Oribela orquestra planos de fuga, com o objetivo de voltar para Portugal. Em uma madrugada ela consegue fugir até a praia. Ao amanhecer, é encontrada por três tripulantes de uma nau. Desesperada, suplica por ajuda, porém, seu corpo é transfigurado novamente em objeto sexual, quando os homens tentam estuprá-la. Ela ainda não entendeu que sua "condição" de mulher e os discursos de dominação masculino a fazem objeto fácil dos anseios de todos aqueles homens. Mas, antes de ser violentada, Francisco consegue resgatá-la, assassinando os três homens.

A partir desse momento, ao romper novamente com o modelo de "boa mulher", é tratada como um animal selvagem. Tornando-se prisioneira do marido, é acorrentada em um pequeno quarto. Dorme no chão e recebe alimentos apodrecidos. Por mais que clame por ajuda, ninguém propõe em resgatá-la, visto que não desrespeitam a autoridade de Francisco. 
A protagonista experimenta todo tipo de castigo físico e simbólico, uma vez que seu caráter rebelde precisa ser contido através dos discursos normativos de conduta feminina expressos pela Igreja. De acordo com Del Priore (1990, p. 25):

A Igreja apropriou-se também da mentalidade androcêntrica presente no caráter colonial e explorou as relações de dominação que presidiam o encontro de homem e mulher, incentivando a última a ser exemplarmente obediente e submissa. A relação de poder já implícita no escravismo reproduzia-se ao nível das relações mais íntimas entre marido e mulher, condenando está a ser uma escrava doméstica, cuja existência se justificasse em cuidar da casa, cozinhar, lavar a roupa, servir ao chefe da família com o seu sexo, dando-lhe filhos que assegurassem a sua descendência e servindo, em última instância, como modelo para a sociedade familiar com que sonhava a Igreja.

Igreja e Estado entendiam que destruído esse sistema de poder sobre as mulheres, o equilíbrio doméstico, a segurança social e a ordem das instituições civis e eclesiásticas entrariam em colapso. Nessa lógica, a força masculina era o único modelo de poder e, essas mulheres, nas palavras de Del Priore (2016), eram normatizadas pelos discursos simbólicos a seguirem tais pressupostos, sobretudo, acerca do pecado original e do pudor. Por exemplo, elas não podiam ostentar sua feminilidade e beleza, "não deviam se olhar no espelho, nem mesmo no da água das banheiras" (DEL PRIORE, 2016, p. 282).

Nesse sentido, Francisco se dispõe a domesticar a esposa, para que obedeça a suas ordens e desejos. Ela é obrigada a ter frequentes relações sexuais, como a se submeter aos desejos invasivos do marido. Del Priore (2016) entende que homens como o personagem Francisco, tratavam “[...] suas mulheres como máquinas de fazer filhos, submetidas às relações sexuais mecânicas e despidas de expressões de afeto" (DEL PRIORE, 2016, p. 363). Ainda nessa perspectiva, Pateman (1993) declara que as esposas eram destinadas unicamente a satisfazerem os desejos e vontades dos maridos (1993, p. 179):

Os homens teriam transformado as mulheres em meras empregadas se não fosse o fato de eles dependerem delas para satisfazerem seus desejos sexuais. Se os homens não tivessem desejo sexual, ou se a multiplicação da espécie não dependesse da intervenção dos homens de uma forma que também lhes dá prazer, não haveriam necessidade da instituição na qual "cada homem traz uma mulher para seu estabelecimento [...]".

Dessa forma, Francisco representa o modelo de homem patriarcal, extremamente insensível e egoísta, expondo toda sua força, autoridade e virilidade. Logo, o "adestramento" do corpo e da mentalidade de mulheres como Oribela, aconteceu "não apenas pela pregação sistemática em favor do matrimônio e contra os 'ilícitos tratos', mas também pela exigência de uma certa compostura, de uma atitude que deveria vigorar na vida social" (DEL PRIORE, 1990, p. 153). Nessa lógica, por meio das constatações da historiadora Roudinesco (2003), é possível afirmar que o arcabouço familiar em que Oribela está inserida, "repousa em uma 
ordem do mundo imutável e inteiramente submetida a uma autoridade patriarcal, verdadeira transposição da monarquia de direito divido" (ROUDINESCO, 2003, p. 19).

Diante disso, a personagem pretende ludibriar o marido, fazendo-o acreditar em sua mudança. Porém, na primeira oportunidade foge novamente. Ela busca auxílio com o personagem Ximeno, que incialmente se recusa em ajuda-la, contudo, acabam se envolvendo amorosamente e sexualmente. Agora, além de fugitiva, torna-se adúltera. No discurso cristão e patriarcal, ela transformou-se em uma figura demonizada, por ter fugido da vida matrimonial e cometido o adultério. Os dois personagens compreendem que ela precisa fugir, então, Ximeno propõe leva-la para o sul da colônia. Durante o trajeto pela praia, percebem que estão sendo perseguidos por Francisco. Apesar da tentativa de fuga, ele consegue alcançálos. Ambos se encontram armados com um mosquete. Oribela está desesperada e procura convencer Francisco a deixá-la partir. O marido afirma que eles estão presos um ao outro, como "duros grilhões", ou seja, por correntes imaginárias oriundas da força simbólica do matrimônio, o qual confere poder supremo ao marido sobre a esposa.

A sequência é o clímax da narrativa. A câmera acompanha os movimentos dos personagens e as "batidas" da trilha sonora conferem agilidade e tensão. Ouvimos e visualizamos dois disparados das armas. A imagem escure em um fade-out. O novo plano é aberto com Oribela novamente gritando e chorando, mas agora, encontra-se concebendo seu primeiro filho.

Observamos que ela se localiza na casa de Francisco, e que ele continua vivo. Não existe nenhuma explicação explicita sobre o desfecho da sequência anterior. Mas, pelo personagem estar vivo, certamente Ximeno está morto. Pois, de acordo com Paulo Rezzutti (2018), o código penal da época legitimava que o homem casado, vítima de adultério, poderia matar sua mulher e o amante, "desde que este fosse de condição social igual ou inferior à do ofendido" (REZZUTTI, 2018, p. 70). Como Ximeno era considerado inferior socialmente, devido sua condição de cristão-novo, certamente foi assassinado por Francisco. Assim, a narrativa finaliza com toda a família e comitiva de escravos saindo da propriedade ao som de uma canção indígena. $\mathrm{O}$ enquadramento final é na criança que Oribela carrega nos braços, deixando subentendido que pode ser filho de Ximeno.

\section{Considerações Finais}

Ao término do filme dois aspectos se destacam acerca da trajetória da personagem Oribela. O primeiro, a liberdade da personagem nunca dependeu somente dos seus esforços enquanto indivíduo, ela necessitou recorrer à força masculina, representada por Ximeno Dias, 
para romper com a dominação do marido Francisco. É perceptível que o roteiro procurou humanizar a imagem de Ximeno, pois é ele quem se sacrifica ao ajudar a protagonista, com um final digno de mártir, e ainda, aparentemente perpetua seu "amor" com um filho na jovem. Segundo, antes de ser mãe, Oribela almejava a todo custo sua libertação do matrimônio. No entanto, a maternidade transforma seus objetivos. Seu epílogo confirma que foi dominada pela estrutura patriarcal em prol do filho. Restando-lhe a única condição de mãe e esposa, contida na estrutura familiar. $\mathrm{O}$ filme termina e a ordem patriarcal do poder masculino colonial é novamente restabelecida.

Nessa linha interpretativa, "Desmundo" figura como um filme histórico, pois retrata temas gerais da história brasileira, como a exploração da mão-de-obra indígena, o conflito de culturas e a força do homem branco europeu. Entretanto, o diretor Alain Fresnot, optou por construir seu enredo e sua protagonista, suprimindo características históricas presentes na literatura de Ana Miranda, informações descritas e interpretadas através do olhar feminino da personagem Oribela, as quais conferem valor histórico e revelam sentidos para as mulheres no romance literário. Em outras palavras, questões do feminino imersos no período da "colonização" brasileira estão presentes na narrativa literária e ocultadas na linguagem fílmica.

Esse aspecto contribuiu na reprodução da recorrente visão masculina no cinema. Primeiro, da mulher enquanto protagonista romantizada que somente encontra nos braços do seu verdadeiro amor, força e suporte para fugir e lutar contra seu algoz. E segundo, que descobre nas graças da maternidade coragem para resistir em um ambiente de dominação. Com isso, Oribela é o retrato da mulher idealizada pelo homem, frágil e forte, heroína destemida que no final, acaba cedendo as forças do desejo masculino.

Entretanto, por mais que a narrativa fílmica reproduza essa visão estereotipada dos gêneros, especialmente do feminino. O filme, como fonte, reconstrói a trajetória de violência e sofrimento das primeiras mulheres no início da fundação do Brasil. Oribela, por mais que represente uma categoria particular de mulher, a branca e cristã, que durante séculos foi referencial de modelo feminino. Também dialoga com a história de mulheres que foram e ainda são vítimas de uma violência sistemática causada pelo poder masculino e que não aceitam o patriarcado como sistema definidor de suas vidas.

Dessa forma, narrativas audiovisuais, como do filme "Desmundo", funcionam como instrumento de visibilidade, representação e testemunho histórico das memórias dessas mulheres no decorrer da história brasileira. Embora a narrativa fílmica carregue visões históricas estereotipadas, ela retrata esse sistema de dominação masculino que ainda 
permanece enraizado em nossa cultura. Assim, mulheres como a personagem Oribela, viveram por séculos, enclausuradas dentro da estrutura familiar, extremamente dominadas pelo poder masculino e pelos discursos normatizadores da Igreja Católica e do Estado, os quais controlavam seus corpos, desejos e sexualidade.

Assim, a representação de Oribela revela aspectos sociais e culturais que alicerçam historicamente nossa sociedade, onde os homens são associados à cultura e as mulheres à natureza, isto é, as figuras femininas apresentam uma função benéfica para a sociedade se estiverem inseridas dentro do ambiente familiar, por meio do matrimônio e consolidadas nas práticas da maternidade. Deste modo, mulheres como a protagonista ao romper com a célula familiar, tornaram-se exemplos maléfico em suas épocas. Nesse viés, o cinema ao representar esse arcabouço histórico envolvendo a construção dos gêneros em nossa sociedade, contribui para o debate do conhecimento acerca da identidade feminina e da história das mulheres. Suscitando discussões e atuando como instrumento na formação da nossa consciência histórica. Transmitindo e/ou salvaguardando memórias individuais e coletivas de personagens e figuras femininas, que foram, em grande maioria, silenciadas nos registros tradicionais da História.

\section{Referências bibliográficas}

ANZUATEGUI, Sabina. Sobre o trabalho de roteirista. In. ANZUATEGUI, Sabina.

FRESNOT, Alain. FERREIRA, Helder (Org.). Roteiro Desmundo. São Paulo: Imprensa Oficial, 2006. p. 17-22.

ARAÚJO, Emanuel. A arte da sedução: sexualidade feminina da Colônia. In. DEL PRIORE, Mary. Histórias das mulheres no Brasil. São Paulo, 2017, p. 45-77.

BAUER, Carlos. Breve história da mulher no mundo ocidental. São Paulo: Xamã: Edições Pulsar, 2001.

CARMO, Paulo Sérgio do. Prazeres e pecados do sexo na história do Brasil. São Paulo: Edições Sesc, 2019.

CESAR, Maria Rita de Assis. Notas para um cinema da diferença. Algumas imagens de mulheres em filmes recentes. In. ADELMAN, Miriam et al. (Org.). Mulheres, homens, olhares e cenas. Curitiba: Editora UFPR, 2011. p. 187-196.

DEL PRIORE, Mary. Ao sul do corpo: condição feminina, maternidade e mentalidades no Brasil Colônia. 1990. Tese (Doutorado em História) - Programa de Pós-Graduação em História, Universidade de São Paulo, São Paulo, 1990. 
DEL PRIORE, Mary. Corpo a corpo com a mulher: pequena história das transformações do corpo feminino no Brasil. São Paulo: Editora Senac, 2000.

DEL PRIORE, Mary. Histórias da gente brasileira: volume I: Colônia. Rio de Janeiro: LeYa, 2016.

FIGUEIREDO, Luciano. Mulheres nas Minas Gerais. In. DEL PRIORE, Mary (Org.). Histórias das mulheres no Brasil. São Paulo, 2017. p. 141-188.

FREYRE, Gilberto. Casa-grande \& senzala: formação da família brasileira sob o regime da economia patriarcal. 48 ed. São Paulo: Global, 2003.

GUBERNIKOFF, Giselle. A imagem: representação da mulher no cinema. Revista Conexão Comunicação e Cultura, Caxias do Sul, v. 8, n. 15, p. 65-77, jan./jun. 2009.

KAMITA, Rosana Cássia. Relações de gênero no cinema: contestações e resistência. Revista Estudos Feministas, Florianópolis, v. 25, n. 3, p. 1393-1404, sept./dec. 2017.

KAPLAN, E. Ann. A mulher e o cinema: Os dois lados da câmera. Rio de Janeiro: Rocco, 1995.

LAURETIS, Teresa de. Através do espelho. Mulher, cinema e linguagem. Revista Estudos Feministas, Florianópolis, v. 1, n. 1, p. 96-122, jan./jun. 1993.

LEITE, Serafim. Cartas do Brasil e mais escritos do P. Manuel da Nóbrega. Coimbra: Universidade de Coimbra, 1955.

NUNES, Maria José Rosado. Freiras do Brasil. In. DEL PRIORE, Mary (Org.). Histórias das mulheres no Brasil. São Paulo, 2017. p. 482-509.

PATEMAN, Carole. O contrato sexual. Rio de Janeiro: Paz e Terra, 1993.

RAMOS, Fábio Pestana. A história trágico-marítima das crianças nas embarcações portuguesas do século XVI. In: PRIORI, Mary Del (Org.). História das crianças no Brasil. São Paulo: Contexto, 2007. p. 19-54.

RAMINELLI, Ronald. Eva Tupinambá. In. DEL PRIORE, Mary (Org.). História das mulheres no Brasil. São Paulo: Contexto, 2017. p. 11-44.

REZZUTTI, P aulo. Mulheres do Brasil: a história não contada. Rio de Janeiro: LeYa, 2018.

ROUDINESCO, Elisabeth. A família em desordem. Rio de Janeiro: Zahar, 2003.

SILVA, Conceição de Maria Ferreira. Mulheres negras e (in)visibilidade: imaginário sobre intersecção de raça e gênero no cinema brasileiro (1990-2009). 2016. Tese (Doutorado em Comunicação) - Programa de Pós-Graduação em Comunicação, Universidade de Brasília, Brasília, 2016.

VAINFAS, Ronaldo. Trópico dos pecados: moral, sexualidade e inquisição no Brasil. Rio de Janeiro: Editora Campus, 1989. 
VIANA, Nildo. Como assistir um filme? Rio de Janeiro: Corifeu, 2009.

Recebido em: 05/01/2020

Aprovado em: 20/02/2021

Publicado em: 07/05 2021

\section{Notas}

* Doutor em História pela Universidade Estadual de Maringá (UEM). Pesquisador do Centro de Estudos das Artes e do Patrimônio Cultura (CEAPAC) do Departamento de História e do Programa de Pós-Graduação em História da Universidade Estadual de Maringá (UEM). http://lattes.cnpq.br/6957046365114878 https://orcid.org/0000-0001-5095-7474

** Doutora em História Social pela Universidade de São Paulo (USP). Pós-Doutora em Patrimônio Cultural pela Universidade Estadual de Campinas (UNICAMP). Docente do Departamento e do Programa de Pós-graduação em História da Universidade Estadual de Maringá (UEM). http://lattes.cnpq.br/7631047969563279 ; http://orcid.org/0000-0002-6584-8323. 